\title{
Multimodal schedule design for synchromodal freight transport systems
}

\author{
Behzad Behdani ${ }^{1}$ \\ Operations Research and Logistics Group, Wageningen University, The Netherlands. \\ Yun Fan' \\ Department of Transport and Planning, Delft University of Technology, The Netherlands.
}

\section{Bart Wiegmans ${ }^{3}$}

Department of Transport and Planning, Delft University of Technology, The Netherlands.

\section{Rob Zuidwijk ${ }^{4}$}

Rotterdam School of Management, Erasmus University, The Netherlands.

\begin{abstract}
Intermodal freight transport has been discussed for decades as an alternative to unimodal road transport. However, it still does not represent a significant portion of the total freight market. A new and promising possibility to improve the performance of freight systems is the synchromodal design of hinterland transport systems. A cornerstone for synchromodality is an integrated view in the design and operation of intermodal transport. A main benefit of this integrated view is an improved flexibility in mode choice in hinterland transport. This paper gives a detailed description of this integrated view for synchromodal freight transport. Based on this description, a mathematical model for designing service schedules for synchromodal freight transport systems is also presented. The benefits of providing integrated transport services compared to separately planned transport services are also discussed for a case in the hinterland network of the Port of Rotterdam.
\end{abstract}

Keywords: freight transportation systems, synchromodal freight transport, multimodal transport, transport service scheduling.

\section{Introduction}

In the last two decades, the main European seaports have experienced a considerable increase in their container throughput (Notteboom and Rodrigue, 2009). Although this trend is significantly influenced by the financial crisis of 2009-2010, the growth in the container ports' throughput has been resumed afterwards to reach 651 million TEUs in 2013 -which is 5.58 percent higher than the global container throughput in 2012 (Rodrigue et a., 2013). To handle larger volumes, many seaports have responded by making investments in new infrastructure and by launching new expansion plans. A recent example is the construction of Maasvlakte 2, which is expected to increase the container handling throughput of Port of Rotterdam from 11.6 million TEU per year in 2013 (Port of Rotterdam, 2014) to 30 million TEU per year by 2035 (Port of Rotterdam, 2011).

\footnotetext{
1 A: Hollandseweg 1, 6706 KN Wageningen, The Netherlands T: +31 317484460 E: behzad.behdani@wur.nl

2 A: Paviljoen G.9 De Rondom 70, 5612AP Eindhoven, The Netherlandss T: +31 402478 886 E: y.fan@tue.nl

${ }^{3}$ A: Stevinweg 1, 2628 CN Delft, The Netherlands T: +31 152782545 E: b.wiegmans@tudelft.nl

4 A: Burgemeester Oudlaan 50, 3062 PA Rotterdam, The Netherlands T: +31 104082235 E: $\underline{\text { rzuidwijk@rsm.nl }}$
} 
Increasing container transport volumes also places higher demand on capacity requirements and performance of hinterland transport. It is well known that hinterland accessibility is as important as port's performance to shaping a seaport's competiveness (e.g., de Langen and Pallis, 2006; Wiegmans et al., 2008). However, as container transport volume continues to grow, hinterland accessibility and connectivity are increasingly crucial factors. This is even more important because nowadays the hinterlands of many seaports (for instance, the hinterland of almost all ports within the Le Havre - Hamburg range in Northern Europe) have expanded from captive to contestable regions (de Langen, 2007). Therefore, major ports increasingly compete with one another. Moreover, the area of influence of a port is no longer only defined by a shorter distance, but also by a cheaper cost and shorter delivery time to the hinterland. Consequently, expansion plans for the container handling capacity of a seaport, without investing in efficient and reliable hinterland access, are not sufficient for well-functioning whole transport chains and cannot guarantee the attractiveness of a port to shippers and carriers (Konings and Priemus, 2008). More efficient hinterland transport may also help to release containers faster and reduce terminal congestion at seaports (Franc and van der Horst, 2010).

In most European countries, unimodal road transport is the dominant mode for inland freight transport (Eurostat Database, 2014). Of course, the modal split varies considerably for different countries - which is primarily dependent on the availability of multiple modalities. For example, in the Netherlands, the share of road transport (in tonne-kilometres) was around $47.1 \%$ in 2013 (which is almost equal to the share taken by inland waterways). In Germany, the shares of road, inland waterways and rail in 2013 have been $70.7 \%, 10.2 \%$ and $19.1 \%$, respectively. Overall, at EU-28 level, almost three-quarters of the total freight inland movement (in tonne-kilometres) were performed by road in 2013. This share has remained more or less stable in the last five years. Although road transport has several advantages in terms of speed and flexibility for hinterland transport, the huge demand for road freight transport leads to undesirable environmental and social impacts (Roso, 2007). A key issue is traffic congestion, particularly in regions around the main seaport. A primary reason for this congestion is that the capacity of road infrastructure is relatively small and, in most cases, less-developed compared to the expected container traffic growth. Accordingly, it can be easily influenced by external conditions such as commuting peak and Working Time Directives of truck drivers (Maloni and Jackson, 2005). This means that for a port like the Port of Rotterdam, over $40 \%$ of vehicles (including container trucks) going to/from Maasvlakte suffer heavy delays (Port of Rotterdam, 2013). The growing container road traffic can also cause many negative environmental impacts. It is estimated that an export/import container emits $5.6 \mathrm{~g} \mathrm{CO} 2 /$ tonne-km if carried by a small containership (444 TEU) and $155 \mathrm{~g} \mathrm{CO} 2 /$ tonne$\mathrm{km}$ if carried by truck (Liao et al., 2009). Additionally, in many cases, plans for expanding the terminal capacity of a seaport receive approval only if strong commitments concerning sustainable hinterland flows are made (Iannone, 2012). For instance, in the case of Maasvlakte 2 in the Port of Rotterdam, for authorization of the project to occur, all parties involved had to agree on a strict modal split target to reduce road haulage in favour of more-sustainable transport modes, i.e., rail and inland shipping (Maasvlakte 2, 2014).

To handle these challenges, Intermodal Freight Transportation (IFT) has been proposed to increase the efficiency of the freight transport system and reduce its externalities (Van Klink and Van den Berg 1998; Janic, 2007). The European Commission (1997) defines IFT as "the movement of goods in one loading unit, which successively uses several modes of transport without handling goods themselves in transhipment between the modes." To be more specific, two or more different transport modes are deployed, and therefore, at least one transhipment takes place; the main haulage is by rail or waterway, whereas road is used for pre- and end-haulage.

Despite the fact that intermodal transport has been discussed for decades, it still does not represent the main portion of the total freight market (Notteboom and Rodrigue, 2009). Unimodal road transport is preferred by some shippers, mostly due to the perception that the service level of intermodal systems would adversely impact their businesses (Woodburn, 2007). 
Meanwhile, the growing demand for speed-to-market product delivery in global supply chains calls for faster, more reliable, and flexible transportation service (Bontekoning and Priemus, 2010). To survive in the intensely competitive transportation market, IFT has to fulfil the growing customers' needs. All of these issues call for new modes of operation to improve service reliability and cost reduction for existing intermodal systems.

A recently discussed concept to promote the market share of IFT is "Synchromodal Freight Transport" (DINALOG, 2014). In this paper, we aim to give a detailed definition of this concept. Additionally, we present a mathematical model to support the service schedule design for such a system. The proposed model can assist the service provider by helping them to better utilize the existing capacity of multiple transport modes at the operational level. The rest of the paper is structured as follows. In Section 2, we discuss the synchromodal transportation concept. Section 3 discusses a hierarchy of decisions for design and operation of Synchromodal Freight Transport Systems. In Section 4, we introduce a mathematical model for synchromodal schedule design. An illustrative case is discussed in Section 5. Finally, in Section 6, we present our conclusions and future research directions.

\section{Definition of Synchromodality}

Synchromodality is a new concept in freight transport that has not yet garnered a precise definition. There is, however, a general agreement that synchromodality encompasses an integrated view of planning and uses different transport modes to provide flexibility in handling transport demand (Figure 1).

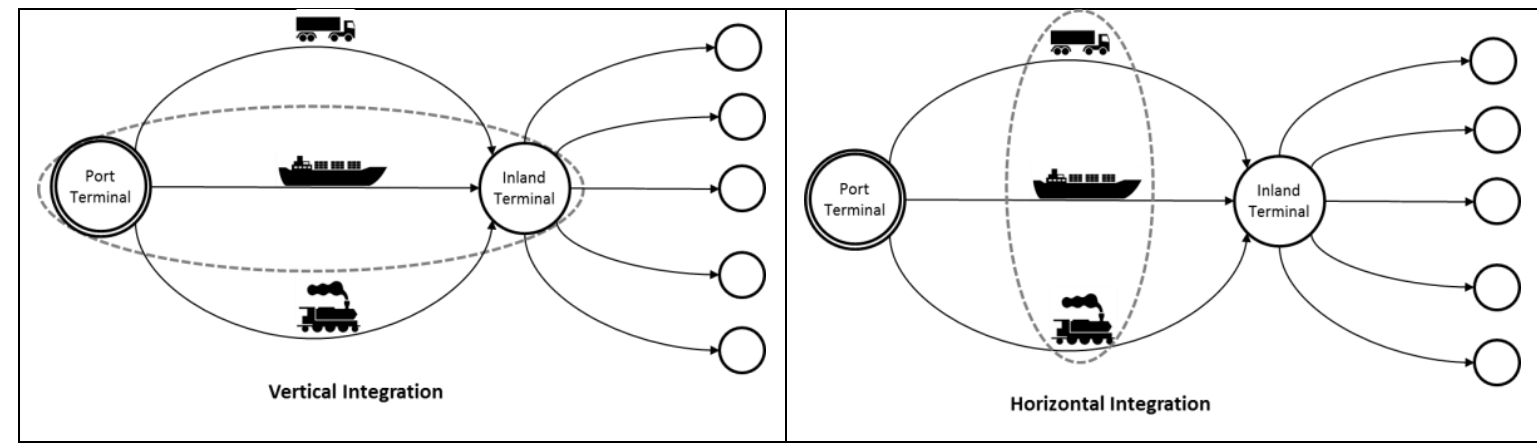

Figure 1. Integrated view of freight transport planning

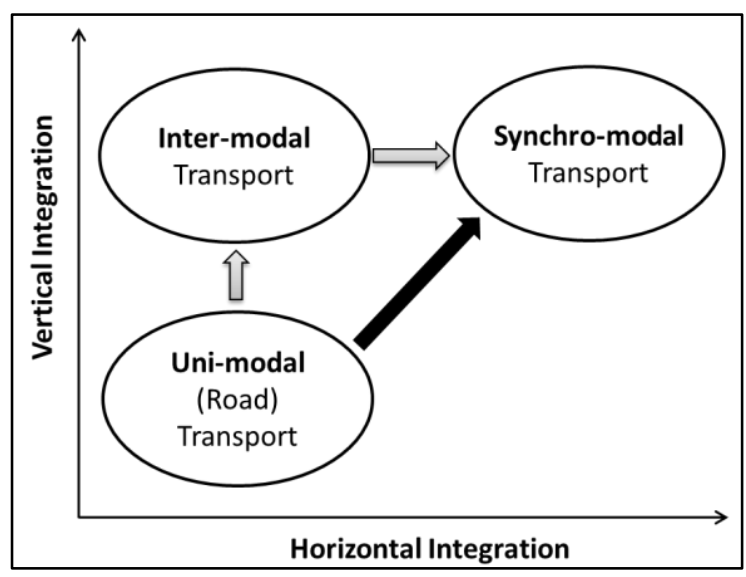

Figure 2. Dual integration in a Synchromodal Freight Transport System

Because different modalities are involved in a door-to-door journey chain, integration of service in multiple transport modes has always been an important issue for intermodal freight transport 
and numerous publications discuss this subject (e.g., Van Der Horst and De Langen, 2008; Rodrigue and Notteboom, 2010; De Borger and De Bruyne, 2011). The majority of these works are focused primarily on vertical integration of logistic services within one transport chain. This vertical integration is the main foundation for "Dry Port" (Roso et al., 2009) and "Extended Gate" (Veenstra et al., 2012) concepts for which some integration of sea terminal operations and inland terminal operations is needed. The distinctive feature of a synchromodal transport system is, however, the horizontal integration or cross-modality integration within a transport system (Figure 2). It proactively integrates the transport service on different modalities as a "coherent transport product" (Gorris et al., 2011). This coherent transport product is called the "Synchromodal Service". The additional level of integration in this service is expected to improve the performance of the whole transport system and results in increased utilization of transport means. It also stimulates the optimal use of all modes of transport, which might lead to a stronger position for IFT. Meanwhile, the growing availability of information in logistics and the transport sector enables further integration and coordination of processes in the hinterland network (Zuidwijk and Veenstra, 2014).

A core assumption when designing synchromodal freight systems is that multiple transport infrastructures (e.g., rail and inland waterways networks) are available to transfer container batches between a maritime and an inland terminal. Synchromodality, then, aims to define an integrated service by looking at the complementary nature of available transport modes. This allows for optimization of trade-offs between the service and cost aspects of multiple modalities within a whole transport system. For instance, although barge transport is cheaper, it is less flexible than trucking. Rail transport is even less flexible because there are specific constraints like shared infrastructure with passenger trains. With this integrated service design, depending on the specific delivery time requirements for each container batch and the availability of each modality, the most appropriate mode will be selected.

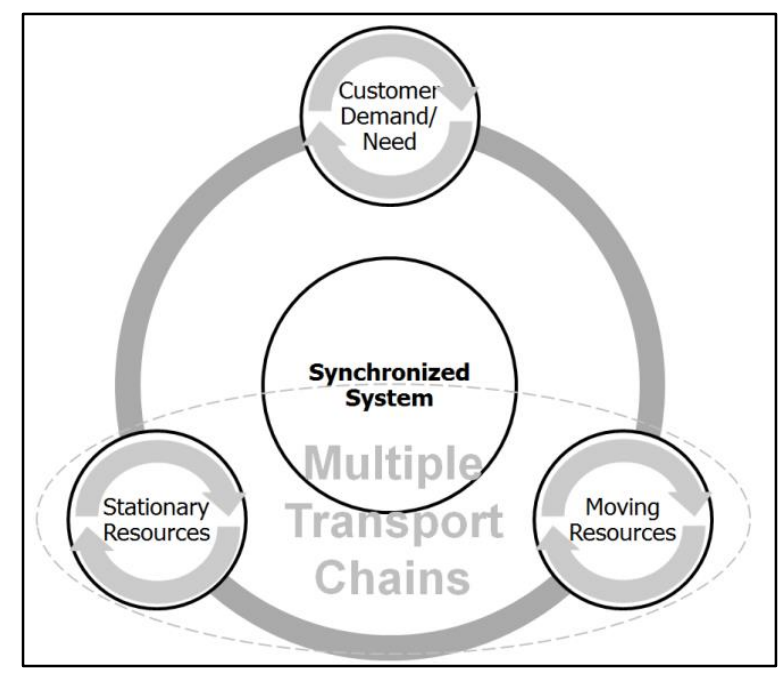

Figure 3. Aspects that must be synchronized in a Synchromodal Freight Transport System

The integration of transport chains in a synchromodal transport system includes synchronizing both "Stationary Resources" - like transport infrastructure (e.g., roads, rails, and navigable waters) or transhipment nodes (e.g., inland terminals) - and "Moving Resources" (e.g., trucks, trains, and barges), which provide the transport services between specific origins and destinations (Figure 3). These resources must be continuously aligned with "Customer Demand" for freight transport service. The integration of resources in synchromodal freight transport system offers several advantages, including favourable economies of scale and increase in service differentiation for different customers. With increased economies of scale - instead of making direct shipments by trucks - the containers can be shipped by a more sustainable transport 
modality to one or more consolidation terminals. This can release the strains on road transport infrastructure (traffic congestion and delays) in the port areas. It may also help to manage the capacity expansion investment in short or medium term.

It is noteworthy to emphasize that multiple actors might be involved in each of the three dimensions of Figure 3. The full value of synchromodality can be achieved if these actors actively coordinate their internal activities and decisions. For instance, in the "Customer Demand" dimension, several shippers in one region may cooperate by bundling their cargo flows or synchronizing empty container flows to provide volume and take advantage of cheaper transport modes. Similarly, in the service provision, multiple logistics service providers may cooperate at the tactical level by joint capacity planning and at the operational level by sharing information to improve network utilization, especially when handling exceptional situations. This can offer greater flexibility in mode choice, improve reliability, make lead time shorter, and increase utilization of road, rail, and inland waterways (Gorris et al., 2011).

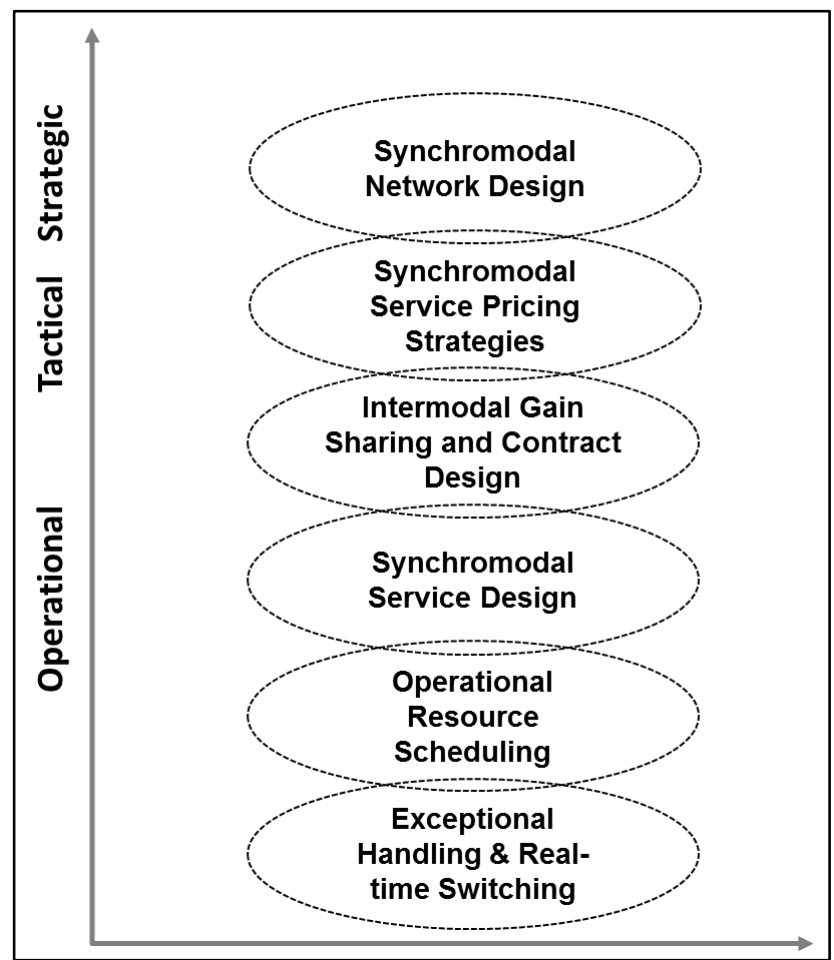

Figure 4. Hierarchy of decision problems in a Synchromodal Freight Transport System

\section{Decision-making in a Synchromodal Freight Transport System}

This section gives an overview of a hierarchy of decision problems involved in the design and operation of a synchromodal freight transport system. These decisions are mainly focused on the synchromodal transport and do not attempt to describe every planning problem in an intermodal transport system. A general overview on planning models for intermodal freight transportation can be found in Macharis and Bontekoning (2004), Crainic and Kim (2007) and Caris et al. (2008).

\section{- Synchromodal Network Design:}

The principal decision at the strategic level is designing the physical network for synchromodal transport (ECT, 2011). This "Synchromodal Network" includes the potential corridors and regions for which a synchromodal service is feasible. This network design primarily depends on the availability of infrastructure (for multiple modalities) and on the adequacy of cargo flow in a specific corridor. Therefore, an in-depth analysis of hinterland transport market, including the market structure, shipment size and frequency of the goods flow between origin and destination 
nodes, would be needed (Janic, 2009). In addition, future developments in the market and the projected demand for transport services must be analysed. Active regional bundling of container flows may also provide more opportunities for synchromodality in a specific hinterland region (Lucassen and Dogger, 2012). Based on this analysis, a network with potential nodes and connections (together with the set of possible modalities in each connection) can be designed. The existing mathematical models for intermodal transport network design can be directly applied to this problem. An extensive review of these models can be found in Crainic and Kim (2007), Alumur and Kara (2008) and SteadieSeifi et al. (2014).

\section{- Synchromodal Service Pricing Strategies:}

A key aspect of synchromodal freight systems is that customers leave mode selection to the service provider (Gorris et al., 2011; Lucassen and Dogger, 2012). Therefore, shippers only book the freight transportation service with determined price and quality requirements, and the synchromodal transport service provider has the freedom to decide on which transport modes to use according to the specifications of the customer and the availability of each mode. This is usually called mode-free booking (Gorris et al., 2011) and is a prerequisite for a Synchromodal Freight Transport System; if shippers book containers on specified transport modes, there is no freedom to integrate the modalities and provide flexibility by switching between different modes based on actual circumstances (e.g., traffic information and real-time availability of modalities).

In a synchromodal pilot study by Lucassen and Dogger (2012), they have found that - although shippers may benefit from a (potentially) cheaper and more reliable intermodal transport service - the most likely advantages of synchromodality benefit the parties offering transport capacity in the network. Therefore, to involve shippers, part of the financial benefits of synchromodality must be transferred to shippers by a fair service pricing scheme. This guarantees the sustainable operation of a synchromodal freight system. For that reason, "Synchromodal Service Pricing" is regarded as a strategic issue in Figure 4. The pricing for intermodal service can also be integrated with operations planning ( $\mathrm{Li}$ and Tayur, 2005) or intermodal service design (Ypsilantis and Zuidwijk, 2013; Li, et al., 2015). For service pricing, the trade-off between the quality (e.g., reliability, speed, sustainability) and operational cost of different modalities must be addressed. In fact, since multiple modalities are "horizontally integrated" in a "single transport service", the quality of service is not necessarily dependent on the modality for the main haulage. Therefore, a "service-based" pricing approach is needed for synchromodality, which is essentially different from the traditional "mode-based" fare design (Lucassen and Dogger, 2012).

\section{- Intermodal Gain Sharing and Contract Design:}

While "Synchromodal Service Pricing Strategies" focus on the shippers' involvement (as external customers), the "Intermodal Gain Sharing and Contract Design" defines how a synchromodal system must be internally coordinated.

A synchromodal transport system aims to integrate the resources in multiple transport chains (ECT, 2011). Each of these chains consists of many companies - like freight forwarders, terminal operators, transport operators, and so on - which are concerned primarily with optimizing their own objectives (Van Der Horst and de Langen, 2008). This self-serving behaviour, together with information asymmetry, leads to poor performance in the whole chain (Cachon, 2002). To achieve optimal performance of a synchromodal system, a comprehensive analysis of relevant actors (with different interests) in the whole transport system is needed (Macharis et al., 2010). Subsequently, the involved parties must be coordinated by contractual relationships and incentives for cooperation. For this purpose, the gains of implementing synchromodality must be shared with fair contracts among all actors. 
The existing literature on horizontal collaboration in the supply chain domain (for example, Cruijssen et al., 2010, Vanovermeire et al., 2014) would be useful to address the gain sharing and contract design for synchromodal freight transport system.

\section{- Synchromodal Service Design:}

Synchromodal planning at the tactical level aims to design synchromodal services. An example of such a service design can be found in Mes and Iacob (2016). The service design can be realized within the framework provided by strategic planning (i.e., Synchromodal Network Design). This includes determination of routes within a hinterland network and the choice of modality for each corridor together with the frequency and capacity of each mode on that corridor (Crainic and Laporte, 1997). Meanwhile, since synchromodality aims at synchronizing the timing of service on multiple modalities, using discrete multi-period models (or Dynamic Service Network Design) would be useful here. A review on Dynamic Service Network Design problem is provided in Wieberneit (2008). For Synchromodal Network Design it might be necessary to decide if the service in a corridor is self-operated or if it is going to be outsourced to other parties (van Riessen et al., 2013). In the latter case, the level of capacity reservation for a specific mode with a third party is also a decision at the tactical level.

\section{- Operational Resource Scheduling:}

Within the constraints of tactical service design (which determines the routes, frequency, and capacity of each modality), the synchromodal transport system must function on a daily basis. This primarily includes determining the timing of operation and assigning container batches to synchromodal services (Mes and Iacob, 2016). This operational schedule considers the details of transport orders (e.g., the due date or size) and also the existing resources (e.g., the time of availability of an inland port or a specific train), and subsequently, assigns the orders to different transport services. For this purpose, a thorough overview of resources and a (centralized) order management system would be needed. To achieve such a level of visibility in multi-modal transport several new concepts and data infrastructure designs like Synchromodal Control Tower has been discussed in the literature (Hofman, 2014).

\section{- Exception Handling and Real-Time Switching:}

The execution of a defined operational schedule must be continuously monitored in real time. Unexpected events (e.g., late arrival of barges, order cancellations, or late releasing of containers) can frequently take place during the operation of a transport system. Due to increased interdependencies between multiple transport chains (and the potential cascading effect of a triggering event), such unexpected events are more likely in a synchromodal transport system. Of course, the integrated view in synchromodal operation would also give more possibilities to handle a disruption. A failure may cause the in-progress schedule to become suboptimal or even infeasible. Subsequently, corrective actions must be taken, and the resources must be (partially) reallocated (Nabais et al., 2013). The cooperation between intermodal hubs and the transport service providers is also beneficial to accommodate the occurrence of an unforeseen event (Nabais et al., 2015). For example, in a case of late releasing of a container - because of customs clearance process- the transport order can be rescheduled on a different service. This is typically called switching (Lucassen and Dogger, 2012). Adjustments in real time require insight into the availability and (expected) utilization of transport assets and infrastructure and call for information sharing among parties in multiple transport chains.

The key point to emphasize here is that not all of the above-mentioned decision problems are addressed in every synchromodal business case. This is primarily dependent on the business models and the actors that are involved in developing a synchromodal freight transport network. For example, for European Gateway Services (EGS), the deep-sea terminal operator makes a contract with ocean carriers or shippers to perform hinterland transport from seaports to inland terminals (ECT, 2014). The hinterland transport is performed by inland waterways, rail and (if 
needed) road. Meanwhile, the transport service in a specific hinterland connection is selfoperated or outsourced to barge operators, road hauliers and rail carriers. Depending on the specific business model and the actors involved in the operation of synchromodal network, different "Service Pricing Strategies" and "Intermodal Gain Sharing" schemes must be designed. Furthermore, the design of a synchromodal network with frequent regular service requires a lot of resource investment and a guarantee of high container transport volume. In the case of European Gateway Services, ECT has enough volume and can offer high-frequent rail and barge services between the Port of Rotterdam and a network of inland terminals. For smaller companies - that are working with fewer shippers with lower demand volumes and possibly, with high variation in logistics requirements - , the design of a network at the strategic level is not typically economically viable. Instead, such a company can design a service network by reserving capacities on multiple modalities and allocating these capacities to transport orders for different shippers. In this case, the focus would be more on tactical and operational decisions in Figure 4.

In general, in a Synchromodal Freight Transport System - by definition - different actors - like barge operator, road hauliers, rail carriers and inland terminal operators - need to collaboratively work in a network. Therefore, in every business model for synchromodality, the "Intermodal Gain Sharing and Contract Design" and "Synchromodal Service Design" are important aspects and are required to be carefully addressed. Additionally, due to the dynamic choice of hinterland mode for container flows in a synchromodal system - and the possibility to switch between different modalities based on actual circumstances- the operational problems - i.e., "Operational Resource Scheduling" and "Exception Handling and Real-Time Switching" - are also relevant for every synchromodal business case.

\section{Mathematical Modelling for Synchromodal Operational Resource Scheduling}

In Section 3, a hierarchy of main decisions for design and operation of a Synchromodal Fright transport system are discussed. These six different decision problems also define how management science approaches (including mathematical modelling and simulation methods) can provide support to facilitate the implementation of Synchromodal Freight Transport Systems.

In developing models for each decision problem, all three dimensions of synchromodality (as shown in Figure 3) must be addressed. Of course, for different decisions, some different requirements have to be fulfilled. For example, while service design at the tactical level is based on the forecasted customer demand, an operational schedule is defined with the actual realization of the demand (i.e., the size and the due date of batches of containers are known). Similarly, the resource constraints are different for the two cases (Figure 5). For service design, the availability and capacity of infrastructure networks or inland terminals are important, whereas at the operational level, the opening hours of terminals, or the timing constraints for using a specific part of the infrastructure need to be considered as constraints in the decision problem. Despite the differences in specific models for each specific decision problem, the vertical integration (and synchronization) of "Moving Resources" and "Stationary Resources" and the horizontal integration - across multiple modalities - needs to be directly reflected in the model design (e.g., by defining constraints to synchronize the timing of operation for barge services and inland terminals). 


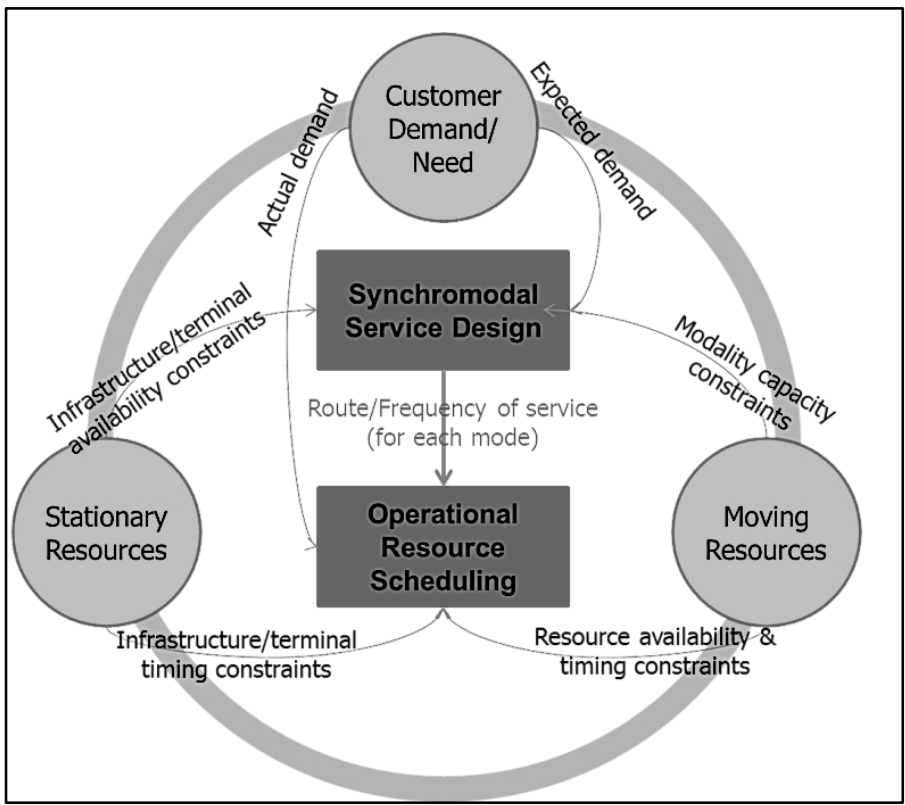

Figure 5. Different synchromodal requirements for different decision problems

In this section, we present a mathematical model for "Operational Resource Scheduling" to elaborate on the application of mathematical modelling in the design and operation of a Synchromodal Freight Transport System. This model takes the frequency and capacity of different modalities as a given and, accordingly, determines the optimal schedule and timing of services for all transport modes. Meanwhile, the assignment of batches of containers to each service is determined by this model.

The service schedule is defined by a service operator, which can be an inland terminal operator, a Third Party Logistics Company, or any intermodal freight transport operator. The main requirement is that such a service provider has access to the demand data and real time information for different modalities and is able to integrate the transport volume to determine the transport schedule accordingly.

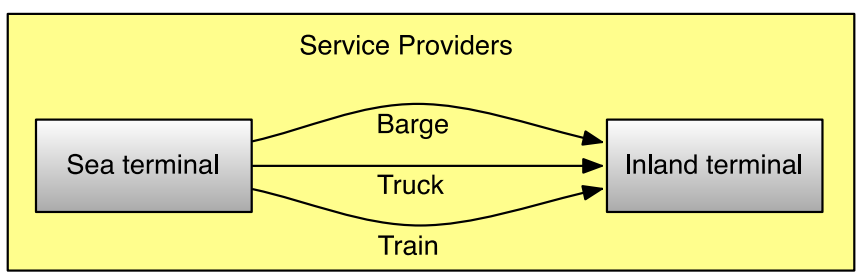

Figure 6. Role of service providers in the synchromodal transport system

To design a synchromodal transport service, multiple performance measures must be addressed. Price and quality are two important factors for customers of the service (Kasilingam, 1998). Consequently, the transport service needs to be provided at a lower cost; that is, the total transportation cost of all modes must be minimized. Quality of transportation service means ontime delivery, reliability, and flexibility. The premise of synchromodality is based on integrating the schedule of multiple transport modes in a way that makes at least one transport service available to send batch of orders on time without delay. Therefore, no delay is allowed in the presented model. Furthermore, for container batches, any unnecessary waiting time at the origin terminal will be penalized. Meanwhile, the flow of containers by barge or train must also be synchronized with opening hours of the destination terminals. Therefore, for rail and barge service, penalties are given to avoid earlier or later arrivals at the destination terminal. 


\subsection{Model Assumptions}

The mathematical model is formulated under the following assumptions:

a) The model considers the synchromodal transport system between one OD pair. Moreover, the rotation of barges in multiple locations at the origin or destination is not considered in the model.

b) Three transport modes are considered in the model: barge, rail, and truck. There is only one route for each transport mode. Moreover, the origin and destination are the same for all modes, and subsequently, there is no transfer between modes during transportation. The service for different modes has different transport costs, service capacities, and waiting times in the terminal.

c) Although the capacity of barge and rail is limited to a specific number of services per day and per week (which is defined by $L_{i j}$ ), no constraint for the number of trucks is considered. Therefore, the model determines only the departure time of barge and rail, while for truck, the departure time is assumed to be flexible.

d) The departure of each service should be within the opening hours of terminals. Earlier and later arrival at the destination is, however, allowed but penalized. This penalty represents the requirement to synchronize the "Stationary" and "Movable" resources as presented in Figure 5.

e) The model uses transportation demand as input. The demand pattern for each OD pair (from " $i$ " to " $j$ ") is assumed to be known and is defined by matrix A, as shown in Figure 7. Each batch of containers, $\mathrm{B}^{(\mathrm{a}, \mathrm{i}, \mathrm{j})}$, is defined by one origin " $i$," one destination " $j$," and " $a$ " which indicates the $a^{\text {th }}$ batch of containers between these two points. In the $a^{\text {th }}$ container batch arrival from origin " $i$ " to destination " $j$," container volume $\mathrm{D}^{(\mathrm{a}, \mathrm{i}, \mathrm{j})}$ arrives at the origin terminal " $i$ " at time $\mathrm{TA}^{(\mathrm{a}, \mathrm{i}, \mathrm{j})}$ and must be delivered to the appointed destination " $j$ " before the due date $\mathrm{TD}^{(\mathrm{a}, \mathrm{i}, \mathrm{j})}$.

\begin{tabular}{c|cc}
$\mathrm{i} \mid \mathrm{j}$ & 1 & 2 \\
\hline 1 & - & $\mathrm{B}^{(\mathrm{a}, \mathrm{i}, \mathrm{j})}$ \\
2 & $\mathrm{~B}^{(\mathrm{a}, \mathrm{i}, \mathrm{j})}$ & -
\end{tabular}

Figure 7. Matrix A for demand pattern from origin " $i$ " to destination " $j$ "

With this input, the output of the optimization model is the departure time of each barge or rail service and the flow of batches transported by each service.

\subsection{Notations}

The following notations are used to describe the problem parameters and variables in the model.

Index:

m

V

i, j

a
Transport modes of service, including barge (B) and rail (R)

Truck service

Origin and destination of service

Number of container batch; $a \in\left\{1, \ldots, \mathrm{N}_{i j}\right\}$

Number " $l$ " service of different modes within a day; $l \in\left\{1, \ldots, L_{i j}\right\}$

The $\mathrm{n}^{\text {th }}$ day in a week; $\mathrm{n} \in\{1, \ldots, \mathrm{N}\}$ 
Behdani, Fan, Wiegmans and Zuidwijk

Multimodal schedule design for synchromodal freight transport systems

Parameters:

$\mathrm{C}_{\mathrm{m}} \quad$ Unit transport cost of mode " $m$ "

$\mathrm{C}_{\mathrm{V}} \quad$ Unit transport cost of truck

$\mathrm{wb}^{(\mathrm{a}, \mathrm{i}, \mathrm{j})} \quad$ Unit waiting penalty of per container batch at origin terminal " $i$ "

$\mathrm{ws}_{\mathrm{m}}^{(\mathrm{i}, \mathrm{j})} \quad$ Unit waiting penalty of service at the destination " $j$ " for mode " $m$ "

$\mathrm{L}_{\mathrm{m}}^{(\mathrm{i}, \mathrm{j})} \quad$ Loading time of mode " $m$ " that departs from " $i$ " to " $j$ "

$\mathrm{T}_{\mathrm{m}}^{(\mathrm{i}, \mathrm{j})} \quad$ Transit time of mode " $m$ " that departs from " $i$ " to " $j$ "

$\mathrm{TT}_{\mathrm{m}}^{(\mathrm{i}, \mathrm{j})} \quad$ Total transit and unloading time of mode " $m$ " that departs from “ $i$ " to ${ }^{\prime \prime} j$ "

$\mathrm{U}_{\mathrm{m}} \quad$ Service capacity of mode " $m$ "

$\mathrm{T}_{\mathrm{on}}^{\mathrm{i}}, \mathrm{T}_{\mathrm{cn}}^{\mathrm{i}} \quad$ Opening time and closing time of origin terminal " $i$ " on day " $n$ "

$\mathrm{T}_{\mathrm{on}}^{\mathrm{j}}, \mathrm{T}_{\mathrm{cn}}^{\mathrm{j}} \quad$ Opening time and closing time of destination terminal “ $j$ " on day " $n$ ”

$\mathrm{DM}_{\mathrm{m}}^{(\mathrm{i}, \mathrm{j})} \quad$ Maximum number of mode " $m$ " service from “ $i$ " to " $j$ " in one day

$\xi \quad$ One day has $\xi$ hours

$\lambda, \mu \quad \lambda$ indicates the latest departure time of rail service in the morning and $\mu$ indicates the earliest departure time of rail service in the evening

Decision Variables:

$\mathrm{x}_{\mathrm{mln}}^{(\mathrm{a}, \mathrm{i}, \mathrm{j})} \quad$ Flow variables represent the part in the demand $\mathrm{D}^{(\mathrm{a}, \mathrm{i}, \mathrm{j})}$ that is transported by mode " $m$ " of service number " $l$ " on day " $n$ "

$\mathrm{t}_{\mathrm{mln}}^{(\mathrm{i}, \mathrm{j})} \quad$ Departure time variables represent the departure time of service number " $l$ " of mode " $m$ " on day " $n$ " from " $i$ " to " $j$ "

$\mathrm{t}_{\mathrm{mln}}^{(\mathrm{a}, \mathrm{i}, \mathrm{j})} \quad$ The departure time of the part in the demand $\mathrm{D}^{(\mathrm{a}, \mathrm{i}, \mathrm{j})}$ that is transported by service " $l$ " of mode " $m$ " on day " $n$ "

$\mathrm{t}^{(\mathrm{a}, \mathrm{i}, \mathrm{j})} \quad$ The departure time of the last portion of batch $D^{(\mathrm{a}, \mathrm{i}, \mathrm{j})}$

$\mathrm{EW}_{\mathrm{mln}}^{(\mathrm{i}, \mathrm{j})} \quad$ The waiting time caused by the earliness of service number " $l$ " of mode " $m$ " on day " $n$ " from " $i$ " to " $j$ " that arrives at the destination terminal $\mathrm{j}$ before its opening time

$\mathrm{LW}_{\mathrm{mln}}^{(\mathrm{i}, \mathrm{j})} \quad$ The waiting time caused by the lateness of service number " $l$ " of mode " $m$ " on day " $n$ " from " $i$ " to " $j$ " that arrives at the destination terminal " $j$ " after its opening time

$\mathrm{y}_{\mathrm{mln}}^{(\mathrm{i}, \mathrm{j})} \quad$ Binary variables represent whether the service " $l$ " of mode " $m$ " on day " $n$ " from " $i$ " to " $j$ " is operated; if it equals 1 , the service is operated, and if it equals 0 , the service is cancelled

$\mathrm{D}_{\mathrm{mln}}^{(\mathrm{a}, \mathrm{i}, \mathrm{j})} \quad$ Binary variable indicates whether batch $\mathrm{D}^{(\mathrm{a}, \mathrm{i}, \mathrm{j})}$ could be delivered by service " $l$ " of mode " $m$ " on day " $n$ ". $\mathrm{D}_{1 \text { mln }}^{(\mathrm{a}, \mathrm{i}, \mathrm{j})}=1$ means that a part of batch $\mathrm{D}^{(\mathrm{a}, \mathrm{i}, \mathrm{j})}$ is delivered by service " $l$ " of mode " $m$ " on day " $n$ "

\subsection{Model Formulation}

Using the above notations, the mathematical model is formulated. 
The model is aimed to operationalize the integrated view for a Synchromodal Freight Transport System - as discussed in section 2. Therefore, the constraints for the operation of "Moving Resources", the integration of "Moving Resources" and "Stationary Resources" (e.g., synchronizing the operation of barge/train services with the timing and operation of inland terminals) and integration of transport operation across multiple modalities, are formulated in the model. A main contribution of this model is in the detailed description of constraints for operational synchronization of operation of "Moving and Stationary Resources". Furthermore, the objective function is aimed at realizing this synchronization (by minimizing the waiting time for containers at the origin terminal, and waiting time for transport services at the destination).

\section{Objective Function:}

The objective of the optimization model is to minimize the total cost of operation, which includes transportation cost of all modes, waiting penalties of container batches at the origin terminal, and waiting penalties for each service at the destination.

$$
\begin{aligned}
& \text { Min } Z=\sum_{(a, i, j) \in A} \sum_{m \in\{B, R\}} \sum_{1 \in\left\{1, \ldots, L_{i j}\right\}} \sum_{n \in\{1, \ldots, N\}} C_{m} \cdot x_{m l n}^{(a, i, j)}+ \\
& \sum_{(a, i, j) \in A} C_{V} \cdot\left[D^{(a, i, j)}-\sum_{m \in\{B, R\}} \sum_{1 \in\left\{1, \ldots L_{i j}\right\}} \sum_{n \in\{1, \ldots, N\}} x_{m l n}^{(a, i, j)}\right]+ \\
& \sum_{(a, \mathrm{i}, \mathrm{j}) \in A} \sum_{m \in\{B, R\}} \sum_{1 \in\left\{1, \ldots, \mathrm{L}_{\mathrm{ij}}\right\}} \sum_{\mathrm{n} \in\{1, \ldots, \mathrm{N}\}} w b^{(\mathrm{a}, \mathrm{i}, \mathrm{j})} \cdot\left[\mathrm{t}^{(\mathrm{a}, \mathrm{i}, \mathrm{j})}-\mathrm{Ta}^{(\mathrm{a}, \mathrm{i}, \mathrm{j})}-\mathrm{L}_{\mathrm{m}}^{(\mathrm{i}, \mathrm{j})}\right]+ \\
& \sum_{(\mathrm{i}, \mathrm{j}) \in \mathrm{OD}} \sum_{m \in\{\mathrm{B}, \mathrm{R}\}} \sum_{1 \in\left\{1, \ldots, \mathrm{L}_{\mathrm{ij}}\right\}} \sum_{n \in\{1, \ldots, N\}} \mathrm{EW}_{\mathrm{mln}}^{(\mathrm{i}, \mathrm{j})} \cdot \mathrm{ws}_{\mathrm{m}}^{(\mathrm{i}, \mathrm{j})}+ \\
& \sum_{(i, j) \in O D} \sum_{m \in\{B, R\}} \sum_{1 \in\left\{1, \ldots, L_{i j}\right\}} \sum_{n \in\{1, \ldots, N\}} L W_{m l n}^{(i, j)} \cdot w_{m}^{(i, j)}
\end{aligned}
$$

The first term in Equation (1) represents the total transportation cost of barge and train service. The second term describes the transportation cost of truck service. Truck volume is calculated by the total demand of batch $\mathrm{D}^{(\mathrm{a}, \mathrm{i}, \mathrm{j})}$ minus volume transported by barge and train. The third term is the total waiting cost of batches at the origin terminal. The waiting cost is the waiting penalty of each batch multiplied by the waiting time of the latest shipped part of each batch. With this penalty term, we can synchronize the timing of a synchromodal service with the time that a container is released for further transport in a seaport. The fourth term is the total waiting cost of early arrival of services. The fifth term is the total waiting cost of the late arrival of services. These terms are introduced to synchronize the timing of transport service provision with the timing of operation of inland terminals and are calculated based on the timing of arrival of a service to an inland terminal and the opening time of that terminal.

\section{Capacity Constraints:}

Constraint (2) limits the capacity per service. If service number " $l$ " of service mode " $m$ " on day " $n$ " is operated (i.e., $\mathrm{y}_{\mathrm{mln}}^{(\mathrm{i}, \mathrm{j})}$ equals 1 ), the total flow of transported batches cannot exceed the maximum capacity for that service $\left(U_{m}\right)$. However, if the service is not operated, there should be no transported volume for this specific service.

$$
\sum_{(\mathrm{a}, \mathrm{i}, \mathrm{j}) \in \mathrm{A}} \mathrm{x}_{\mathrm{mln}}^{(\mathrm{a}, \mathrm{i}, \mathrm{j})} \leq \mathrm{U}_{\mathrm{m}} \mathrm{y}_{\mathrm{mln}}^{(\mathrm{i}, \mathrm{j})} \quad \forall(\mathrm{i}, \mathrm{j}) \in \mathrm{OD}, \mathrm{m} \in\{\mathrm{B}, \mathrm{R}\}, \mathrm{l} \in\left\{1, \ldots, \mathrm{L}_{\mathrm{ij}}\right\}, \mathrm{n} \in\{1, \ldots, \mathrm{N}\}
$$

\section{Flow Constraints:}

Constraint (3) shows the flow constraint. Because total demand should be transported, the flow that is transported by barge and rail service should be less than or equal to the total volume of the container batch. Clearly, the difference between the total volume of each batch and the combined 
parts of the batch transported by barge and train must be sent by truck to the destination terminal.

$$
\mathrm{D}^{(\mathrm{a}, \mathrm{i}, \mathrm{j})}-\sum_{\mathrm{m} \in\{\mathrm{B}, \mathrm{R}\}} \sum_{\mathrm{l} \in\left\{1, \ldots, \mathrm{L}_{\mathrm{ij}}\right\}} \sum_{\mathrm{n} \in\{1, \ldots, \mathrm{N}\}} \mathrm{x}_{\mathrm{mln}}^{(\mathrm{a}, \mathrm{i}, \mathrm{j})} \geq 0 \quad \forall(\mathrm{a}, \mathrm{i}, \mathrm{j}) \in \mathrm{A}
$$

\section{Delivery Time Constraints:}

These constraints define the timing for departure and delivery of batches. Constraint (4) states that the departure time of the service should be within the opening hours of each day. $\mathrm{T}_{\mathrm{on}}^{\mathrm{i}}+$ $\xi(n-1)$ is the opening time of the origin terminal on day " $n$ ". Correspondingly, $T_{c n}^{i}+\xi(n-1)$ is the closing time of the origin terminal on day " $n$ ". The departure time of number " $l$ " in service of mode " $m$ " on day " $n$ " should be within the opening hour of that day.

$$
\mathrm{T}_{\mathrm{on}}^{\mathrm{i}}+\xi(\mathrm{n}-1) \leq \mathrm{t}_{\mathrm{mln}}^{(\mathrm{i}, \mathrm{j})} \leq \mathrm{T}_{\mathrm{cn}}^{\mathrm{i}}+\xi(\mathrm{n}-1) \quad \forall(\mathrm{i}, \mathrm{j}) \in \mathrm{OD}, \mathrm{m} \in\{\mathrm{B}, \mathrm{R}\} \mathrm{l} \in\left\{1, \ldots, \mathrm{L}_{\mathrm{ij}}\right\}, \mathrm{n} \in\{1, \ldots, \mathrm{N}\}
$$

Constraints (5) to (7) represent that the waiting time of a batch at the origin and they should be non-negative. Moreover, delay at the destination is not allowed.

$$
\mathrm{t}_{\mathrm{mln}}^{(\mathrm{i}, \mathrm{j})} \geq \mathrm{TA} \mathrm{A}^{(\mathrm{a}, \mathrm{i}, \mathrm{j})}+\mathrm{L}_{\mathrm{m}}^{(\mathrm{i}, \mathrm{j})}-\mathrm{M} \cdot\left(1-\mathrm{D}_{\mathrm{mln}}^{(\mathrm{a}, \mathrm{i}, \mathrm{j})}\right) \quad \forall(\mathrm{a}, \mathrm{i}, \mathrm{j}) \in \mathrm{A}, \mathrm{m} \in\{\mathrm{B}, \mathrm{R}\}, \mathrm{l} \in\left\{1, \ldots, \mathrm{L}_{\mathrm{ij}}\right\}, \mathrm{n} \in\{1, \ldots, \mathrm{N}\}
$$

In constraint (5), $\mathrm{D}_{\mathrm{mln}}^{(\mathrm{a}, \mathrm{i}, \mathrm{j})}$ shows whether the service number " $l$ " of mode " $m$ " on day " $n$ " is chosen to transport a portion of batch $\mathrm{D}^{(\mathrm{a}, \mathrm{i}, \mathrm{j})}$. If it equals 1 , the arrival time of the container batch plus the loading time $\left(\mathrm{Ta}^{(\mathrm{a}, \mathrm{i}, \mathrm{j})}+\mathrm{L}_{\mathrm{m}}^{(\mathrm{i}, \mathrm{j})}\right.$ ) should be earlier than the departure time of service, that is $t_{\mathrm{mln}}^{(\mathrm{i}, \mathrm{n})}$. Because of the big $\mathrm{M}$, this constraint will always be true if the service is not chosen. In this case, constraint (6) limits the flow of a batch with a specific service.

$$
\mathrm{x}_{\mathrm{mln}}^{(\mathrm{a}, \mathrm{i}, \mathrm{j})} \leq \mathrm{M} \cdot \mathrm{D}_{\mathrm{mln}}^{(\mathrm{a}, \mathrm{i}, \mathrm{j})} \quad \forall(\mathrm{a}, \mathrm{i}, \mathrm{j}) \in \mathrm{A}, \mathrm{m} \in\{\mathrm{B}, \mathrm{R}\}, \mathrm{l} \in\left\{1, \ldots, \mathrm{L}_{\mathrm{ij}}\right\}, \mathrm{n} \in\{1, \ldots, \mathrm{N}\}
$$

Finally, constraint (7) avoids the delay in delivering batches to the destination terminals. In this constraint, $\left(\mathrm{t}_{\mathrm{mln}}^{(\mathrm{i}, \mathrm{j})}+\mathrm{TT}_{\mathrm{m}}^{(\mathrm{i}, \mathrm{j})}\right)$ is the time in which the transportation service is completed-including transit and unloading time - which should be earlier than the due time of the batch of containers.

$$
\mathrm{TD}^{(\mathrm{a}, \mathrm{i}, \mathrm{j})} \geq \mathrm{t}_{\mathrm{mln}}^{(\mathrm{i}, \mathrm{j})}+\mathrm{TT}_{\mathrm{m}}^{(\mathrm{i}, \mathrm{j})}-\mathrm{M} \cdot\left(1-\mathrm{D}_{\mathrm{mln}}^{(\mathrm{a}, \mathrm{i}, \mathrm{j})}\right) \quad \forall(\mathrm{a}, \mathrm{i}, \mathrm{j}) \in \mathrm{A}, \mathrm{m} \in\{\mathrm{B}, \mathrm{R}\}, 1 \in\left\{1, \ldots, \mathrm{L}_{\mathrm{ij}}\right\}, \mathrm{n} \in\{1, \ldots, \mathrm{N}\}
$$

Constraints (8) to (10) define the departure time of the last portion of each batch, that is, $\mathrm{D}^{(\mathrm{a}, \mathrm{i}, \mathrm{j})}$. In this constraint, $t_{\mathrm{mln}}^{(\mathrm{a}, \mathrm{i}, \mathrm{j})}$ will be equal to the departure time of each portion and constraint (10) finds the departure time of the last part $t^{(a, i, j)}$ of specific batch $D^{(a, i, j)}$, which is used in the objective function to calculate the waiting penalty.

$$
\begin{array}{ll}
\mathrm{t}_{\mathrm{mln}}^{(\mathrm{a}, \mathrm{i}, \mathrm{j})} \geq \mathrm{t}_{\mathrm{mln}}^{(\mathrm{i}, \mathrm{j})}-\mathrm{M}\left(1-\mathrm{D}_{\mathrm{mln}}^{(\mathrm{a}, \mathrm{i}, \mathrm{j})}\right) & \forall(\mathrm{a}, \mathrm{i}, \mathrm{j}) \in \mathrm{A} \\
\mathrm{t}_{\mathrm{mln}}^{(\mathrm{a}, \mathrm{i}, \mathrm{j})} \leq \mathrm{t}_{\mathrm{mln}}^{(\mathrm{i}, \mathrm{j})}+\mathrm{M}\left(1-\mathrm{D}_{\mathrm{mln}}^{(\mathrm{a}, \mathrm{i}, \mathrm{j})}\right) & \forall(\mathrm{a}, \mathrm{i}, \mathrm{j}) \in \mathrm{A} \\
\mathrm{t}^{(\mathrm{a}, \mathrm{i}, \mathrm{i}, \mathrm{j})} \geq \mathrm{t}_{\mathrm{mln}}^{(\mathrm{a}, \mathrm{i}, \mathrm{j})} & \forall(\mathrm{a}, \mathrm{i}, \mathrm{j}) \in \mathrm{A}
\end{array}
$$

If a terminal is not operating $24 / 7$, it is necessary to add some constraints to the model that limit the departure or arrival time of a service and define earliness and lateness. Based on the model assumption, the latest arrival time of the service departing in one day should be before closing time of the next day. However, there can be two situations of arrival out of the opening hours: (1) service on day " $n$ " arrival earlier than the opening time of the terminal of day " $n$ " and (2) service on day " $n$ " arrival later than the closing time of day " $n$ " and earlier than the opening time of day " $n+1$." If one service departs on day " $n$ " and arrives at the destination after the opening time of day " $n+1$," there is no waiting time for lateness.

Constraints (11) and (12) describe the waiting time of early arrival. If there is an early arrival, the waiting time should be equal to the opening time $\left(\mathrm{T}_{\mathrm{on}}^{\mathrm{j}}+\xi(\mathrm{n}-1)\right)$ minus the arrival time 
$\left(\mathrm{t}_{\mathrm{mln}}^{(\mathrm{i}, \mathrm{j})}+\mathrm{T}_{\mathrm{m}}^{(\mathrm{i}, \mathrm{j})}\right)$. The early arrival time is 0 if the service arrives at the terminal within the opening hours.

$$
\begin{array}{ll}
\mathrm{EW}_{\mathrm{mln}}^{(\mathrm{i}, \mathrm{j})} \geq \mathrm{T}_{\mathrm{on}}^{\mathrm{j}}+\xi(\mathrm{n}-1)-\mathrm{t}_{\mathrm{mln}}^{(\mathrm{i}, \mathrm{j})}-\mathrm{T}_{\mathrm{m}}^{(\mathrm{i}, \mathrm{j})} & \forall(\mathrm{i}, \mathrm{j}) \in \mathrm{OD}, \mathrm{m} \in\{\mathrm{B}, \mathrm{R}\}, 1 \in\left\{1, \ldots, \mathrm{L}_{\mathrm{ij}}\right\}, \mathrm{n} \in\{1, \ldots, \mathrm{N}\} \\
\mathrm{EW}_{\mathrm{mln}}^{(\mathrm{i}, \mathrm{j})} \geq 0 & \forall(\mathrm{i}, \mathrm{j}) \in \mathrm{OD}, \mathrm{m} \in\{\mathrm{B}, \mathrm{R}\}, 1 \in\left\{1, \ldots, \mathrm{L}_{\mathrm{ij}}\right\}, \mathrm{n} \in\{1, \ldots, \mathrm{N}\}
\end{array}
$$

Constraints (13) to (17) are for the late arrival of services at the destination terminals. If there is lateness, according to constraint (14), $\mathrm{D}_{\mathrm{mln}}^{(\mathrm{i}, \mathrm{j})}$ has to be 1 , and waiting time could be calculated by constraint (13). If there is no lateness, which means that the service arrives at the destination before the closing time, $\mathrm{D}_{\mathrm{mln}}^{(\mathrm{i}, \mathrm{j})}$ could be 0 or 1 . The constraint (14) is always true. Because the objective is to minimize the waiting penalty at the destination terminal, $\mathrm{LW}_{\mathrm{mln}}^{(\mathrm{i}, \mathrm{j})}$ will be 0 in this case. If the arrival of service is after the opening time of the destination terminal of day " $n+1$ ", $\mathrm{D}_{\mathrm{mln}}^{(\mathrm{i}, \mathrm{j})}$ is 1 and $\left(\mathrm{T}_{\mathrm{o}(\mathrm{n}+1)}^{\mathrm{j}}+\xi \mathrm{n}\right) \cdot \mathrm{D}_{\mathrm{mln}}^{(\mathrm{i}, \mathrm{j})}-\left(\mathrm{t}_{\mathrm{mln}}^{(\mathrm{i}, \mathrm{j})}+\mathrm{T}_{\mathrm{m}}^{(\mathrm{i}, \mathrm{j})}\right)$ is less than 0 . Constraint (15) makes the waiting time equal to 0 .

$$
\begin{aligned}
& \mathrm{LW}_{\mathrm{mln}}^{(\mathrm{i}, \mathrm{j})} \geq\left(\mathrm{T}_{\mathrm{o}(\mathrm{n}+1)}^{\mathrm{j}}+\xi \mathrm{n}\right) \cdot \mathrm{D}_{\mathrm{mln}}^{(\mathrm{i}, \mathrm{j})}\left(\mathrm{t}_{\mathrm{mln}}^{(\mathrm{i}, \mathrm{j})}+\mathrm{T}_{\mathrm{m}}^{(\mathrm{i}, \mathrm{j})}\right) \quad \forall(\mathrm{i}, \mathrm{j}) \in \mathrm{OD}, \mathrm{m} \in\{\mathrm{B}, \mathrm{R}\}, 1 \in\left\{1, \ldots, \mathrm{L}_{\mathrm{ij}}\right\}, \mathrm{n} \in\{1, \ldots, \mathrm{N}\} \\
& \left(\mathrm{T}_{\mathrm{cn}}^{\mathrm{j}}+\xi(\mathrm{n}-1)\right)-\left(\mathrm{t}_{\mathrm{mln}}^{(\mathrm{i}, \mathrm{j})}+\mathrm{T}_{\mathrm{m}}^{(\mathrm{i}, \mathrm{j})}\right)+\mathrm{M} \cdot \mathrm{D}_{\mathrm{mln}}^{(\mathrm{i}, \mathrm{j})} \geq 0 \quad \forall(\mathrm{i}, \mathrm{j}) \in \mathrm{OD}, \mathrm{m} \in\{\mathrm{B}, \mathrm{R}\}, 1 \in\left\{1, \ldots, \mathrm{L}_{\mathrm{ij}}\right\}, \mathrm{n} \in\{1, \ldots, \mathrm{N}\} \\
& \mathrm{LW}_{\mathrm{mln}}^{(\mathrm{i}, \mathrm{j})} \geq 0 \\
& \mathrm{t}_{\mathrm{c}(\mathrm{n}+1)}^{\mathrm{j}}+\xi \mathrm{n} \geq \mathrm{t}_{\mathrm{mln}}^{(\mathrm{i}, \mathrm{j})}+\mathrm{T}_{\mathrm{m}}^{(\mathrm{i}, \mathrm{j})} \\
& \mathrm{D}_{\mathrm{mln}}^{(\mathrm{i}, \mathrm{j})} \in[0,1]
\end{aligned}
$$

Constraint (16) shows that the arrival of service 1 of mode $m$ departing on day " $n$ " should be earlier than the closing time of the destination terminal on day " $n+1$ ". Constraint (17) is for binary variables.

\section{Service Sequence Constraints:}

In order to make a balanced service schedule, the number of services moving back and forth must be equal:

$$
\sum_{\mathrm{l} \in\{1, \ldots, \mathrm{L}\}} \mathrm{y}_{\operatorname{mln}}^{(\mathrm{i}, \mathrm{j})}=\sum_{\mathrm{l} \in\{1, \ldots, \mathrm{L}\}} \mathrm{y}_{\mathrm{mln}}^{(\mathrm{j}, \mathrm{i})} \quad \forall(\mathrm{i}, \mathrm{j}) \in \mathrm{OD}, \mathrm{m} \in\{\mathrm{B}, \mathrm{R}\}, \mathrm{n} \in\{1, \ldots, \mathrm{N}\}
$$

Constraint (19) represents the total number of services of mode " $m$ " within a day and should be within the maximum number.

$$
\sum_{\mathrm{l} \in\{1, \ldots, \mathrm{L}\}} \mathrm{y}_{\mathrm{mln}}^{(\mathrm{i}, \mathrm{j})} \leq \mathrm{DM}_{\mathrm{m}}^{(\mathrm{i}, \mathrm{j})} \quad \forall(\mathrm{i}, \mathrm{j}) \in \mathrm{OD}, \mathrm{m} \in\{\mathrm{B}, \mathrm{R}\}, \mathrm{n} \in\{1, \ldots, \mathrm{N}\}
$$

Constraints (20) and (21) are for the sequence of service number. Constraint (20) states that, if the number 1 service of mode $m$ on day $n$ is not operated, the number " $l+1$ " service cannot be operated. Constraint (21) states that departure of service should be in sequence. If both $\mathrm{y}_{\mathrm{m}(\mathrm{i}, \mathrm{j}) \mathrm{1}(\mathrm{1}) \mathrm{n}}$ and $\mathrm{y}_{\mathrm{mln}}^{(\mathrm{i}, \mathrm{j})}$ equal 1 , it means that both number " $l$ " and " $l+1$ " services are operated, and the departing time of service " $l+1$ " should be larger than that of service " $l$ ".

$$
\begin{array}{ll}
\mathrm{y}_{\mathrm{m}(1+1) \mathrm{n}}^{(\mathrm{i}, \mathrm{j})} \leq \mathrm{y}_{\mathrm{mln}}^{(\mathrm{i}, \mathrm{j})} & \forall(\mathrm{i}, \mathrm{j}) \in \mathrm{OD}, \mathrm{m} \in\{\mathrm{B}, \mathrm{R}\}, \mathrm{l} \in\left\{1, \ldots, \mathrm{L}_{\mathrm{ij}}\right\}, \mathrm{n} \in\{1, \ldots, \mathrm{N}\} \\
\mathrm{t}_{\mathrm{m}(\mathrm{i}, \mathrm{j})}^{(1+1) \mathrm{n}} \mathrm{t}_{\mathrm{mln}}^{(\mathrm{i}, \mathrm{i})} \geq \mathrm{M}\left(\mathrm{y}_{\mathrm{m}(\mathrm{i}, \mathrm{j})}^{(\mathrm{i}) \mathrm{n})}+\mathrm{y}_{\mathrm{mln}}^{(\mathrm{i}, \mathrm{j})}-2\right) & \forall(\mathrm{i}, \mathrm{j}) \in \mathrm{OD}, \mathrm{m} \in\{\mathrm{B}, \mathrm{R}\}, 1 \in\left\{1, \ldots, \mathrm{L}_{\mathrm{ij}}\right\}, \mathrm{n} \in\{1, \ldots, \mathrm{N}\}
\end{array}
$$

\section{Infrastructure Usage Constraint:}

Infrastructure constraint is only considered for the departure time of rail service in this case. Because the freight trains are operated on the same railway track as passenger trains, there are infrastructure constraints for freight rail service. In other words, in the rail system, we may assume that passenger trains have higher priority than cargo trains, and subsequently, the 
departure time of rail service is constrained to some specific periods. For example, in Figure 8, we assume that departures of rail services are allowed early in the morning or late in the evening.

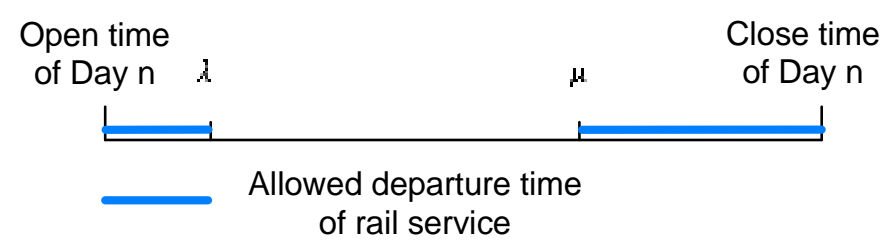

Figure 8. Allowed departure times of rail service

Constraint (22) is for departing early in the morning. Constrain (23) is for late departure in the evening. In constraint (24), the sum of $\mathrm{D} 1_{\mathrm{Rln}}^{(\mathrm{i}, \mathrm{j})}$ and $\mathrm{D} 2_{\mathrm{Rln}}^{(\mathrm{i}, \mathrm{j})}$ should equal $\mathrm{y}_{\mathrm{Rln}}^{(\mathrm{i}, \mathrm{j})}$ because the departure of rail service is determined by $\mathrm{y}_{\mathrm{Rln}}^{(\mathrm{i}, \mathrm{j})}$.

$$
\begin{array}{ll}
\mathrm{t}_{\mathrm{R} l n} \leq[\lambda+\xi(\mathrm{n}-1)]+\mathrm{M}\left(1-\mathrm{D} 1_{\mathrm{Rln}}^{(\mathrm{i}, \mathrm{j})}\right) & \forall(\mathrm{i}, \mathrm{j}) \in \mathrm{OD}, \mathrm{l} \in\left\{1, \ldots, \mathrm{L}_{\mathrm{ij}}\right\}, \mathrm{n} \in\{1, \ldots, \mathrm{N}\} \\
{[\mu+\xi(\mathrm{n}-1)]-\mathrm{M}\left(1-\mathrm{D} 2_{\mathrm{Rln}}^{(\mathrm{i}, \mathrm{j})}\right) \leq \mathrm{t}_{\mathrm{Rln}}} & \forall(\mathrm{i}, \mathrm{j}) \in \mathrm{OD}, \mathrm{l} \in\left\{1, \ldots, \mathrm{L}_{\mathrm{ij}}\right\}, \mathrm{n} \in\{1, \ldots, \mathrm{N}\} \\
\mathrm{D} 1_{\mathrm{Rln}}^{(\mathrm{i}, \mathrm{j})}+\mathrm{D} 2_{\mathrm{Rln}}^{(\mathrm{i}, \mathrm{j})}=\mathrm{y}_{\mathrm{Rln}}^{(\mathrm{i}, \mathrm{j})} & \forall(\mathrm{i}, \mathrm{j}) \in \mathrm{OD}, \mathrm{l} \in\left\{1, \ldots, \mathrm{L}_{\mathrm{ij}}\right\}, \mathrm{n} \in\{1, \ldots, \mathrm{N}\} \\
\mathrm{D} 1_{\mathrm{mln}}^{\mathrm{i}, \mathrm{i})}, \mathrm{D} 2_{\mathrm{mln}}^{(\mathrm{i}, \mathrm{j})} \in[0,1] &
\end{array}
$$

Non-negativity Constraints:

There are other constraints for binary variables and the constraints of non-negativity of variables.

$$
\begin{aligned}
& \mathrm{x}_{\mathrm{mln}}^{(\mathrm{a}, \mathrm{b})(\mathrm{i}, \mathrm{j})}, \mathrm{t}_{\mathrm{mln}}^{(\mathrm{i}, \mathrm{j})}, \mathrm{t}_{\mathrm{mln}}^{(\mathrm{a}, \mathrm{b})(\mathrm{i}, \mathrm{j})}, \mathrm{t}^{(\mathrm{a}, \mathrm{b})(\mathrm{i}, \mathrm{j}) \geq 0} \\
& \mathrm{y}_{\mathrm{mln}}^{(\mathrm{i}, \mathrm{j})}, \mathrm{D}_{\mathrm{mln}}^{(\mathrm{a}, \mathrm{b})(\mathrm{i}, \mathrm{j})} \in[0,1]
\end{aligned}
$$

\section{An Illustrative Case Study}

To illustrate the applicability of the presented model, in this section we present and discuss the design of a synchromodal service schedule for container transportation between PoR, a sea terminal, and Tilburg, an inland terminal. The idea for the case is from a synchromodality pilot study that has been carried out between Rotterdam, Moerdijk and Tilburg by TNO in 2012 (Lucassen and Dogger, 2012). The focus of this paper in on multimodal transport between Port of Rotterdam (PoR) and Tilburg. In this corridor all possible modalities (i.e., barge, rail and truck)

\begin{tabular}{|c|c|c|c|c|c|c|c|c|c|}
\hline \multirow{2}{*}{ Mode } & \multirow[t]{2}{*}{$\begin{array}{l}\text { Cost } \\
(€ / T E U)\end{array}$} & \multirow{2}{*}{$\begin{array}{l}\text { Waiting } \\
\text { penalty } \\
\text { (€/hour) }\end{array}$} & \multirow[t]{2}{*}{$\begin{array}{l}\text { Capacity } \\
\text { (TEU) }\end{array}$} & \multirow{2}{*}{$\begin{array}{l}\text { Maximum } \\
\text { number of } \\
\text { service per } \\
\text { day }\end{array}$} & \multicolumn{3}{|c|}{$\begin{array}{l}\text { Loading/unloading } \\
\text { (hour) }\end{array}$} & \multicolumn{2}{|l|}{$\begin{array}{l}\text { Transit } \\
\text { (hour) }\end{array}$} \\
\hline & & & & & $\begin{array}{l}\text { PoR } \\
\text { Tilburg }\end{array}$ & $\begin{array}{ll}\text { - } & \text { Tilburg } \\
& \text { PoR }\end{array}$ & & $\begin{array}{l}\text { PoR - } \\
\text { Tilburg }\end{array}$ & $\begin{array}{l}\text { Tilburg - } \\
\text { PoR }\end{array}$ \\
\hline Barge & 45 & 80 & 40 & 5 & 1.25 & 1.25 & & 9 & 9 \\
\hline Rail & 60 & 100 & 110 & 1 & 3 & 3 & & 3 & 3 \\
\hline Truck & 90 & - & - & - & - & - & & - & - \\
\hline
\end{tabular}
exist along each other. The cost and time parameters are defined based on the available scientific literature and expert evaluations. These are summarized in Table 1. Regarding terminal operating hours, we assumed that PoR operates 24/7, while the Tilburg terminal operates between 6:00 and 22:00 from Monday to Saturday.

Table 1. Main assumptions in the illustrative case 
The demand pattern of two directions is represented by matrix A and $\mathrm{A}^{\prime}$; matrix $\mathrm{A}$ shows the transport demand from PoR to Tilburg, while $\mathrm{A}^{\prime}$ represents the demand from Tilburg to PoR. For this case, the two matrices are estimated based on the yearly throughput, assuming that it is uniformly distributed over all weeks. To experiment with the presented model, an assumed demand pattern for both direction with volumes, arrival times at origin, and due times is generated, as shown in Table 2.

Table 2. Container transport demand data for a random week (a) from PoR to Tilburg (matrix A), (b) from Tilburg to PoR (matrix A')

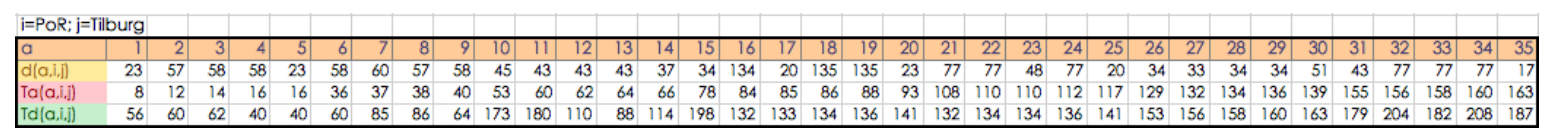

(a)

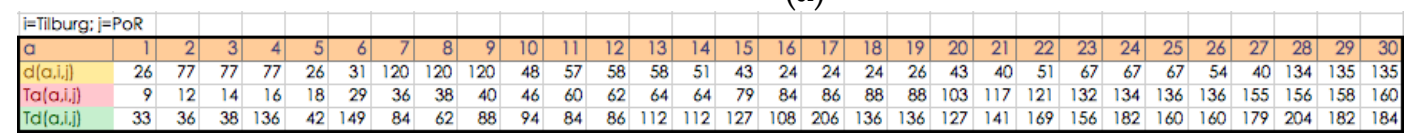

(b)

Using the presented model for integrated service design, the optimal schedule for barge and rail services is determined. To compare the results, two other cases are also considered.

- Base Case: There is no coordination between barge and rail services in the base case. Four barge services per day from Monday to Sunday and one daily rail service from Monday to Saturday are defined in both directions. The departure times for barge services are at 9:00, 13:00, 17:00, and 21:00, and rail service is at 20:00. Based on the total transit time and unloading time at the destination for barge or rail service, the earliest available service that can deliver the batch on time is selected. If there is no available barge or rail service for some portion of the batches, a truck is considered to avoid delay at the destination.

- Sequential Service: In this case, the optimal schedule for barge and rail is determined separately. First, the optimal schedule for barge services is defined. With a fixed determined schedule for barge, in the next stage, the optimal schedule for rail service is calculated.

Table 3. Results for three cases

\begin{tabular}{|c|c|c|c|c|}
\hline & & Base case & $\begin{array}{l}\text { Sequential } \\
\text { service }\end{array}$ & $\begin{array}{l}\text { Integrated } \\
\text { service }\end{array}$ \\
\hline Total Service Cost & & 314763 & 262085 & 250706 \\
\hline Transport Cost & & 239310 & 231735 & 228630 \\
\hline Barge & & 80460 & 88515 & 94230 \\
\hline Train & & 51660 & 50700 & 45480 \\
\hline Truck & & 107190 & 92520 & 88920 \\
\hline $\begin{array}{l}\text { Container Batches V } \\
\text { Penalty }(O)\end{array}$ & Vaiting & 61173 & 28130 & 16516 \\
\hline Service Waiting Pen & alty (D) & 14280 & 2220 & 5560 \\
\hline Barge & & 7680 & 1220 & 4660 \\
\hline Train & & 6600 & 1000 & 900 \\
\hline Modal Split & Barge (\%) & 46.5 & 51.2 & 54.5 \\
\hline & Train (\%) & 22.3 & 22 & 19.7 \\
\hline & Truck (\%) & 31.2 & 26.8 & 25.8 \\
\hline Service Utilization & Barge $(\%)$ & 79.8 & 87.8 & 93.5 \\
\hline & Train (\%) & 81.5 & 80 & 71.8 \\
\hline
\end{tabular}


The results of modelling for these cases are shown in Table 3. Compared with the base case, the integrated service design results in $€ 64,057$ of cost savings (which is a more than a $20 \%$ improvement). These cost savings can first be attributed to lowered transport costs, as fewer trucks are used for the integrated service case. The waiting penalty at the origin terminal is also reduced. The cost savings for the integrated case in comparison with the sequential service design is about $5 \%$. Furthermore, the results show that the integrated schedule design improves the modal split by increasing the share of more sustainable transport modes (i.e., barge and rail). Similarly, the utilization of barge and rail capacity is increased in the integrated case. All of these show the value of the presented model to define an integrated multimodal schedule compared with institutive methods for designing schedules by practitioners.

The results of the presented model can be used to define the schedule of service-by-service operators. A representation of such schedules for PoR-to-Tilburg and Tilburg-to-PoR is presented in Figure 9.

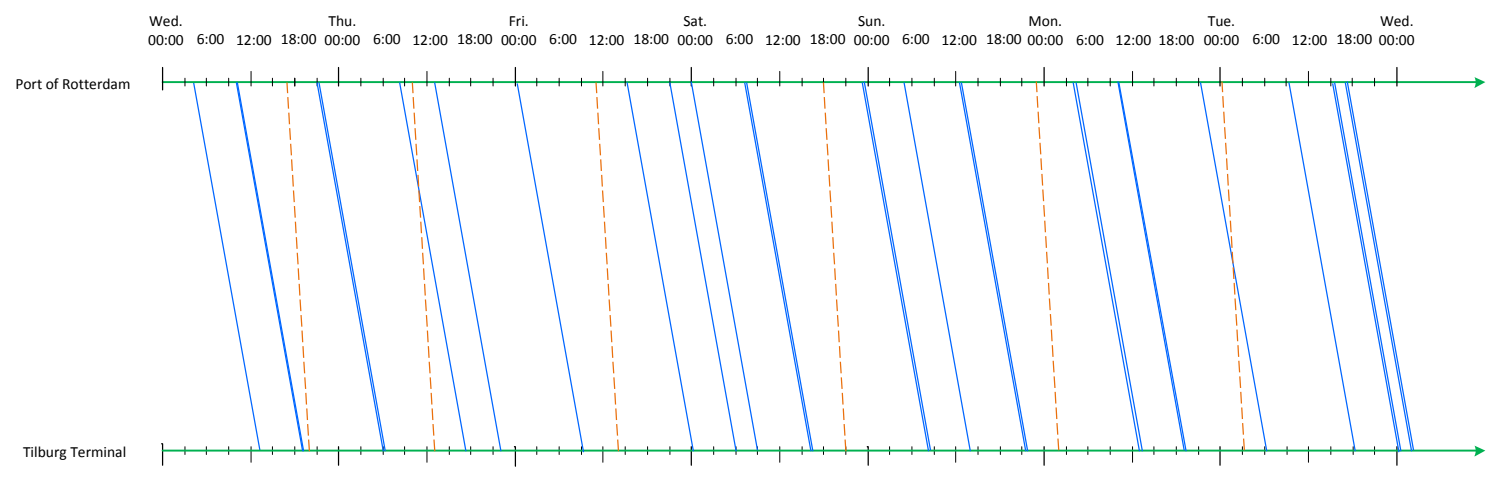

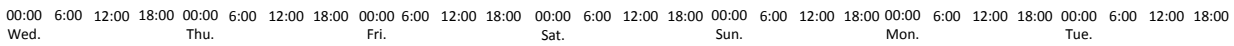

Barge service from port of Rotterdam to Tilburg -

Barge service from port of Rotterdam to Tilburg
Rail service from port of Rotterdam to Tilburg

(a)

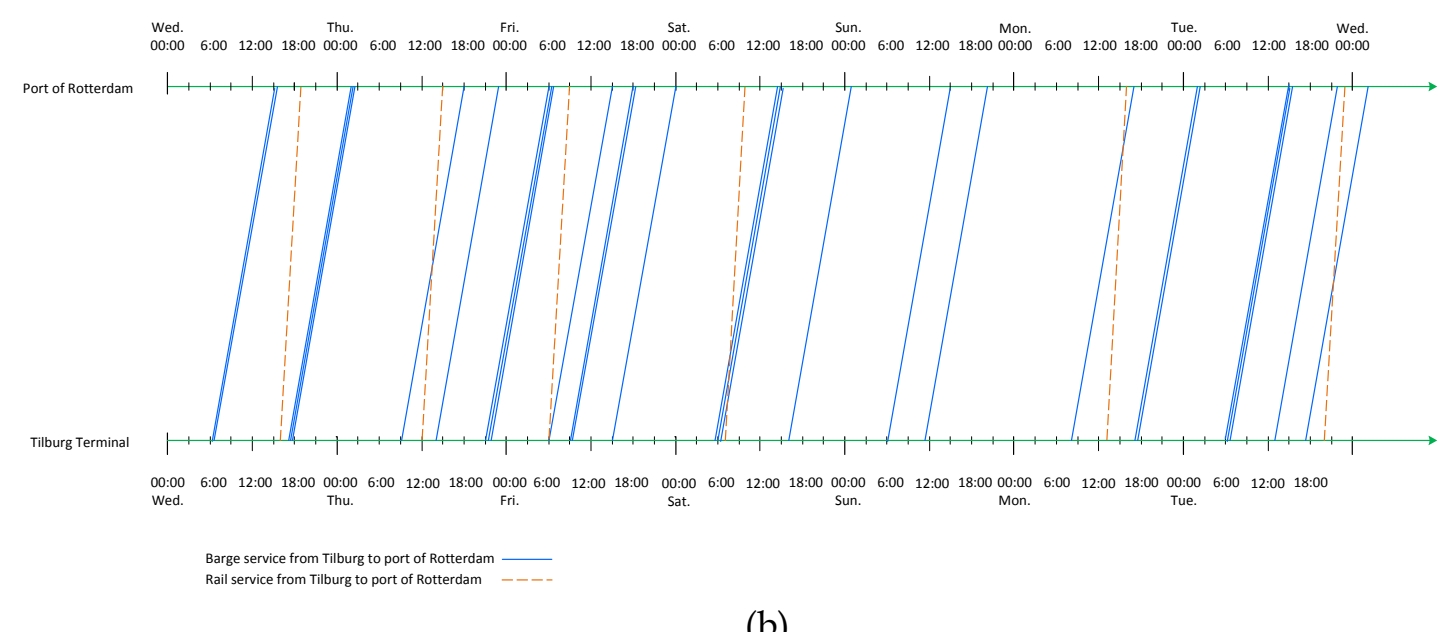

(b)

Figure 9. Timing of service in the integrated design case (a) from PoR to the Tilburg terminal, and (b) and from the Tilburg terminal to POR.

\section{Discussion and Concluding Remarks}

The ability to utilize multiple modes of transport in an orchestrated manner in synchromodal transportation has a considerable impact on the accessibility of seaports. A cornerstone of synchromodality is an integrated view in the design and operation of intermodal freight 
transport systems. This integration includes both vertical integration, which aims at synchronizing the operation of moving resources (e.g., barge or trains) and stationary resources (e.g., inland terminals), and horizontal integration to synchronize the operation of multiple modalities as a "single transport service". A detailed encounter of this integrated view in a Synchromodal Freight Transport System is presented in the paper. Furthermore, we present the set of decisions needed for design and operation of a Synchromodal Freight Transport System. Realising this integration in a Synchromodal Freight Transport System is driven and challenged by several factors. These factors include both hard (or technical) and soft (or socio-organizational) aspects. As a technical challenge, the synchronization requires integrated information solutions to accommodate the time-critical transfer of data among different actors in different transport chains. The integration of modalities also calls for new organizational and legal arrangements. Firstly, synchromodality may give rise to some new business models and the change of roles in hinterland transport. This is already happening, for example, in the extended gate service in which - instead of carriers or shippers - the terminal operator is responsible for the operation of inland transport -"terminal operator haulage" vs. "merchant haulage" or "carrier haulage" (Notteboom and Rodrigue, 2009). These changes create new legal responsibilities and liabilities for actors. Moreover, the coordination of actors involved in a Synchromodal Freight Transport System can be very challenging and needs some different contractual and partnership arrangements. In order to facilitate the collaboration and information, the public government parties - like port authorities - can actively work as neutral actors in the chain. Furthermore, they can facilitate this integration by removing some legal barriers (e.g., different costumes processes/documents for different modalities) and consequently, providing the flexibility for service providers to switch between different transportation modes. The public sector can also plan for the development of infrastructure to create a core network of synchromodal hinterland connections.

In addition to a qualitative analysis of synchromodality, we present a mathematical model for operational schedule design in a Synchromodal Freight Transport System in this paper. The presented model is developed based on the integrated view as discussed in the paper. Therefore, it provides a detailed description of constraints for operational synchronization of moving and stationary resources in an intermodal transport system. The proposed model is expected to provide support for intermodal service providers that intend to offer transport services between a maritime terminal and hinterland ports. It allows planners to determine an optimal schedule of multiple transport modalities for a specific time horizon. To illustrate the applicability of this model, a case of hinterland freight transport between port of Rotterdam and one inland terminal (in this case, Tilburg) is also modelled. The case of PoR-Tilburg is especially interesting for synchromodal analysis since multiple modalities (barge, rail and truck) exist along each other in this corridor. The numerical experiments for scenarios of synchronized and sequential service design in this case show some improvements for intermodal freight transport system. To form a definitive conclusion regarding the general value of synchromodality, more cases are indeed needed. To further evaluate the model and the conclusions, our future work will focus on other cases (including more real-life applications) and demand patterns. The model can also be extended for cases with multiple nodes. Furthermore, exploring the impact of unexpected events-like barge delays or terminal closings - and extending the model for cases with intermediate transit terminals are other possible directions for future research. Likewise, there are uncertain waiting times in the seaports which can be incorporated into the model. Finally, the presented model does not include the effect of volumes (and economies of scale) on the costs. For many cases in practice, the marginal costs of an additional intermodal service are low. Therefore, another extension would be appropriate to make the number of service and ship sizes endogenous in the model. 
Behdani, Fan, Wiegmans and Zuidwijk

Multimodal schedule design for synchromodal freight transport systems

\section{References}

Alumur, S., Kara, B.Y., 2008. Network hub location problems: the state of the art. European Journal of Operational Research, 190 (1), 1-21.

Bontekoning, Y. M., Macharis, C. and Trip, J. J. (2004). Is a new applied transportation research field emerging?--A review of intermodal rail-truck freight transport literature. Transportation Research Part A: Policy and Practice, 38(1), 1-34.

Bontekoning, Y. and Priemus, H. (2010). Breakthrough innovations in intermodal freight transport. Transportation Planning and Technology, 27(5), 335-345.

Cachon, G. (2003). Supply chain coordination with contracts, In Graves, S. and de Kok, T. (ed.) Handbooks in Operations Research and Management Science: Supply Chain management.

Caris, A., Macharis, C. and Janssens, G. K. (2008). Planning problems in intermodal freight transport: accomplishments and prospects. Transportation Planning and Technology, 31(3), 277-302.

Crainic, T.G. and Laporte, G. (1997). Planning models for freight transportation. European Journal of Operational Research, 97(3), 409-438.

Crainic, T., and Kim, K. (2007). Intermodal transportation. In Barnhart, C. and Laporte, G. (ed.) Handbooks in Operations Research and Management Science: Transportation.

Cruijssen, F. C. A. M., Dullaert, W. and Joro, T. (2010). Logistic efficiency through horizontal cooperation: The case of Flemish road transportation companies. International Journal of Logistics Research and Applications, 13(3), 161-178.

De Borger, B. and De Bruyne, D. (2011). Port activities, hinterland congestion, and optimal government policies: the role of vertical integration in logistic operations, Journal of Transport Economics and Policy, 45(2), 247-275.

de Langen, P.W. and Pallis, A.A. (2006). Analysis of the benefits of intra-port competition. International Journal of Transport Economics, 33(1), 69-86.

de Langen, P. (2007). Port competition and selection in contestable hinterlands: the case of Austria. European Journal of Transport and Infrastructure Research, 7(1), 1-14.

DINALOG (2014). Synchromodal http://www.dinalog.nl/en/themes/synchromodal_transport. Accessed Dec. 2015.

Transport.

European Commission (1997). Intermodality and Intermodal Freight Transport in the European Union, http://cordis.europa.eu/transport/src/taskforce/src/comift.htm. Accessed Dec. 2015.

Eurostat Database (2014). Freight transport statistics - modal split. http://ec.europa.eu/eurostat/statistics-explained/index.php/Freight_transport_statistics__modal_split. Accessed Dec. 2015.

ECT (2014). European Gateway Services, www.europeangatewayservices.com, Accessed Dec. 2015.

ECT (2011), Synchromodality in Practice, Fast Forward, Issue 51, 8 -11, http:/ / myservices.ect.nl/SiteCollectionDocuments/0457.1087\%20Fast\%20Forward\%2051\%20Summer \%202011_LOW2.pdf. Accessed Dec. 2015.

Franc, P. and Van der Horst, M. (2010). Understanding hinterland service integration by shipping lines and terminal operators: a theoretical and empirical analysis. Journal of Transport Geography, 18(4), 557566.

Gorris, T., Groen, T., Hofman, W., Janssen, R., Van Meijeren, J., Oonk, M., et al. (2011). Implementatieroadmap Synchromodaliteit. TNO, Connekt and Dinalog commissioned by the Ministry of Infrastructure and Environment. 
Behdani, Fan, Wiegmans and Zuidwijk

Multimodal schedule design for synchromodal freight transport systems

Hofman, W. (2012). Control tower architecture for multi- and synchromodal logistics with real time data. Paper presented at the $5^{\text {th }}$ International Conference on Information Systems, Logistics and Supply Chain (ILS 2014), 2014, Breda, the Netherlands.

Iannone, F. (2012). The private and social cost efficiency of port hinterland container distribution through a regional logistics system. Transportation Research Part A: Policy and Practice, 46(9), 1424-1448.

Janic, M. (2007). Modelling the full costs of an intermodal and road freight transport network. Transportation Research Part D: Transport and Environment, 12(1), 33-44.

Janic, M. (2009). Modeling the Cost of Performance of a Given Logistics Network Operating Under Regular and Irregular Conditions. European Journal of Transport and Infrastructure Research, 9(2):100-120.

Kasilingam, R. (1998). Logistics and Transportation: Design and Planning, Kluwer Academic Publishers, the Netherlands.

Konings R., and Priemus, H. (2008). Terminals and the competitiveness of container barge transport. Transportation Research Record: Journal of the Transportation Research Board, 2062(1), 39-49.

Li, L., Tayur, S. (2005). Medium-term pricing and operations planning in intermodal transportation. Transportation Science, 39(1), 73-86.

Li, L., Lin, X., Negenborn, R. R. and De Schutter, B. (2015). Pricing Intermodal Freight Transport Services: A Cost-Plus-Pricing Strategy. In Corman, F., Voß, S. and Negenborn, R. R. (Eds.) Proceedings of the 6th International Conference on Computational Logistics (ICCL 2015), Springer International Publishing.

Liao, C.-H., Tseng, P.H. and Lu, C.S. (2009). Comparing carbon dioxide emissions of trucking and intermodal container transport in Taiwan. Transportation Research Part D: Transport and Environment, 14(7), 493-496.

Lucassen, I. M. P. J. and Dogger, T. (2012). Synchromodality pilot study. Identification of bottlenecks and possibilities for a network between Rotterdam, Moerdijk and Tilburg., TNO.

Maasvlakte 2 (2014). Master Plan for Hinterland Transport. https://www.maasvlakte2.com/en/index/show/id/594/Master+Plan+for+hinterland+transport.

Accessed Dec. 2015.

Macharis, C., De Witte, A. and Turcksin, L. (2010). The Multi-Actor Multi-Criteria Analysis (MAMCA) application in the Flemish long-term decision making process on mobility and logistics. Transport Policy, 17(5), 303-311.

Maloni, M. and Jackson, E.C. (2005). North American Container Port Capacity: An Exploratory Analysis. Transportation Journal, 44(3), 1-22.

Mes, M. R. and Iacob, M. E. (2016). Synchromodal Transport Planning at a Logistics Service Provider. In Zijm, H., Klumpp, M., Clausen, U. and ten Hompel M. Logistics and Supply Chain Innovation, Springer International Publishing.

Nabais, J. L., Negenborn, R. R., Carmona-Benítez, R. and Botto, M. A. (2015). Cooperative Relations among Intermodal Hubs and Transport Providers at Freight Networks Using an MPC Approach. In Corman, F., Voß, S. and Negenborn, R. R. (Eds.) Proceedings of the 6th International Conference on Computational Logistics (ICCL 2015), Springer International Publishing.

Nabais, J. L., Negenborn, R. R. and Botto, M. A. (2013). Model predictive control for a sustainable transport modal split at intermodal container hubs. Paper presented at the $10^{\text {th }}$ IEEE International Conference on Networking, Sensing and Control (ICNSC), 2013, Paris.

Notteboom, T. and Rodrigue, J.P. (2009). The future of containerization: perspectives from maritime and inland freight distribution. GeoJournal, 74(1), 7-22.

Port of Rotterdam (2011). Port Vision 2030: Port Compass. http://www.portofrotterdam.com/en/Port/port-in-general/port-vision-2030/Pages/default.aspx. Accessed Dec. 2015. 
Behdani, Fan, Wiegmans and Zuidwijk

Multimodal schedule design for synchromodal freight transport systems

Port of Rotterdam (2013). Annual Report 2012. www.portofrotterdam.com/annualreport. Accessed Dec. 2015.

Port of Rotterdam (2014). Annual Report 2013. www.portofrotterdam.com/annualreport. Accessed Dec. 2015.

Rodrigue, J.P. and Notteboom, T. (2010). Foreland-based regionalization: integrating intermediate hubs with port hinterlands, Research in Transportation Economics, 27(1), 19-29.

Rodrigue, J.-P., Comtois, C. and Slack, B. (2013). The Geography of Transport Systems. Routledge, New York.

Roso, V. (2007). Evaluation of the dry port concept from an environmental perspective. Transportation Research Part D: Transport and Environment, 12(7): 523-527.

Roso, V., Woxenius, J. and Lumsden, K. (2009). The dry port concept: connecting container seaports with the hinterland. Journal of Transport Geography, 17(5), 338-345.

SteadieSeifi, M., Dellaert, N. P., Nuijten, W., Van Woensel, T., and Raoufi, R. (2014). Multimodal freight transportation planning: A literature review. European Journal of Operational Research, 233(1), 1-15.

Van Der Horst, M.R. and de Langen, P.W. (2008). Coordination in hinterland transport chains: a major challenge for the seaport community, Journal of Maritime Economics \& Logistics, 10(1-2), 108-129.

Van Klink, H.A. and Van den Berg, G.C. (1998). Gateways and intermodalism. Journal of Transport Geography, 6(1), 1-9.

Van Riessen, B., Negenborn, R.R., Dekker, R., Lodewijks, G. (2013). Service network design for an intermodal container network with flexible due dates/times and the possibility of using subcontracted transport. In Fu, X. et al. (ed) Proceedings of the International Forum on Shipping, Ports and Airports.

Vanovermeire, C., Sörensen, K., Van Breedam, A., Vannieuwenhuyse, B. and Verstrepen, S. (2014). Horizontal logistics collaboration: decreasing costs through flexibility and an adequate cost allocation strategy. International Journal of Logistics Research and Applications, 17(4), 339-355.

Veenstra, A., Zuidwijk, R., van Asperen, E. (2012). The extended gate concept for container terminals: expanding the notion of dry ports. Maritime Economics and Logistics, 14(1), 14-32.

Wiegmans, B. W., Van Der Hoest, A. and Notteboom, T. E. (2008). Port and terminal selection by deepsea container operators. Maritime Policy and Management, 35(6), 517-534.

Woodburn, A. (2007). The role for rail in port-based container freight flows in Britain. Maritime Policy \& Management, 34(4), 311-330.

Wieberneit, N. (2008). Service network design for freight transportation: a review. OR Spectrum, 30(1), $77-112$

Zuidwijk, R., and Veenstra, A. (2014). The value of information in container transport. Transportation Science (in press). 